\title{
Losing my Western Baggage: An autobiographical case for relocating human rights within cultural studies discourse
}

\author{
Pearl Hunt \\ Simon Fraser University \\ pearlh@sfu.ca
}

\begin{abstract}
What is it about music that allows people to transcend difference? Can what we learn about music's abilities inform an enhanced conversation of difference and be applied to the theory of education and critical pedagogy? These questions form the basis of my inquiry into music and social change, an investigation that I have largely focused in North America during the twentieth century. I had the opportunity to further this inquiry and explore the structural roots of music while participating in an adult education conference at the source of Nile in Uganda in the year 2004.

The following personal narrative articulates my experiences in Africa and is an attempt to counter the dominant paternalistic hegemony often ascribed towards Africa and its people. In the course of actually losing my luggage, I became aware of Africa and the Africans I met as a place and people of generosity and discovery. In particular, I have been inspired by Africans' writing both within the continent and in the Diaspora, continue to offer to both cultural studies theory and cultural practices. It is within the framework of cultural studies and human rights theory that I begin to identify a space in which music operates as a collective entity.

By building north-south and east-west dialogues, working within and outside the academy, African intellectuals, activists, and artists continue to enrich our cultural landscape. My writing then, is an initial attempt to demonstrate the need to develop a more inclusive critical pedagogy that will benefit from the work of African scholarship and practice.
\end{abstract}

\section{Introduction}

In this article, I move between auto-ethnographic field notes and cultural theories, conveying my learning process as I encountered Africa and Africans, both by being on the continent and in reading the work of Africans on the continent and in the diasporas. I examine the interplay and tensions of collective identities and human rights agency as representative cultural and structural components of social change. In particular, I examine how music in communal performance becomes a site that allows our collective identities to become manifest.

By examining the fields of cultural studies and social movement discourse, I offer reflections upon the significant contributions which African cultural studies has made to the development of a praxis based cultural studies. How this praxis is realized through performative acts is central to articulating my cultural work within social justice movements and is also an attempt to further the discussion of development and its

Journal of Contemporary Issues in Education, 2007, 2(2), pp. 38-52.

ISSN 1718-4770 (C) 2007 University of Alberta

http://ejournals.library.ualberta.ca/index.php/JCIE 
relationship to both cultural studies and peace education pedagogy.

Entebbe, Uganda: 23:05, June 6, 2004

The plane touched down on the runway of Entebbe's airport at 23:05 June 6, 2004, just as scheduled. I had been in the air for almost two days, leaving Vancouver, Canada at 13:00 on June $5^{\text {th }}$ with transfers in London Heathrow and Nairobi, Kenya. And now, here I was in the airport of Entebbe, Uganda, with my carry-on handbag and my Gibson guitar in its beat-up hard case, the case I had schlepped across the skies in my makeshift wheelie cart that became more of a hassle than help. My checked baggage, though, was nowhere to be found.

The airport was bustling, as were the green suited, red tasseled, extra security due to the Ugandan President, Yoweri Museveni's imminent arrival. Surrounded by colourpeople wearing loose fitting traditional printed shirts and skirts to tailored suits - I could feel the midnight heat. I was longing to get out of these close quarters and into the African night. Eventually we were stewarded into a receiving area to get our documentation and passports stamped. My official documentation listed me as NGO (Non Governmental Organization) Input. My purpose of this travel was to gather with a transnational collective of peace educators to attend the global conference Mpambo One People, Multiple Dreams of a Different World.

Over two hundred participants were expected from Nigeria, Sweden, USA, UK, Lesotho, Malaysia, Sri Lanka, India, Kenya, Tanzania, South Africa, Ghana, Guyana, Jamaica, Egypt, Zimbabwe, New Zealand, Australia, Botswana, Canada, Switzerland, Pakistan, and Uganda. The conference was the third in a series of international conferences exploring alternatives for people and planet; the first was held in New Delhi, India in February 2001; and the second in Victoria, British Columbia, Canada in November 2003. The paper I was presenting entitled, Music as a Vehicle to Balance Education and Transformative Praxis, was safely tucked into the side pocket of my checked baggage- the same baggage that got lost somewhere between Vancouver and Entebbe.

Losing my baggage became symbolic of my travels in Uganda. Without my western baggage, I had to rely on the resources of the people and place. This, in turn, led me not only to be more open to the experience of Africa and the generosity of the people I met there, but I also, began to question the western baggage we bring to the study of Africa. In order to counter this dominant western narrative I am putting this baggage aside for the time being.

\section{A few theoretical observations}

"Culture is always a step ahead of its definitions and descriptions." Spivak (2006, 360).

To begin, I want to position myself within the framework of cultural studies. In terms of what Wright (2003) and others identify as activist cultural studies, I have been a cultural worker for over thirty years, beginning in the populist theatre movement in Canada in the 1970's and the Fluxus inspired performance art movement of the 1970's 
and 1980's that sought to relocate aesthetics within a socio-political context. ${ }^{\mathrm{i}}$ Originating through the artist run center, the Western Front, in Vancouver, B.C., the work was largely concerned with informing both content and form in an interdisciplinary and collaborative context. What began, as our experimental initiatives in media and performance in the early 1970's are now part of mainstream popular culture, as an example, the music video. ${ }^{\text {ii }}$

Fluxus artists, such as Yoko Ono, continue to transform and question the idea of public space and performance. In a recent Ono installation "Wish Tree", as part of World Peace Forum (2006), ${ }^{\text {iii }}$ visitors were invited to write down their wishes for the world on paper tags (leaves) and attached them with string to several fabricated trees. The installation, situated in the downtown east side of Vancouver, had messages ranging from hoping for a "ham sandwich" to prayers for "world peace." Ono's work is representative of the way in which cultural practice can be connected to social movements and by extension cultural theory. It is with a similar intention of connecting cultural work with social justice praxis that I embark on African cultural studies.

Cultural studies is a product of relocating social justice within academic discourse but this relocation is often clothed in northern/western epistemologies that continue to marginalize nonwestern states. Grossberg (2004) reiterates this problem, "The 'proper' voice of cultural studies is almost always, with a kind of unreflective inevitability that is frightening considering what we claim to be doing, located within the West, and even more, within the English speaking world, and even more, in Britain and the United States," (p. xiv) ${ }^{\text {iv }}$. Even during the populist theatre explosion in Canada during the 1970's whereby we resisted institutionalized, repertory theatres and British and American authors in favour of collective and collaborative open-air creations, we were still largely influenced by the Brechtian model of populist theatre and did not look beyond western or Euro-centric performative expressions.

During this same period (1976-77) in Africa, was the emergence of the People's Theatre at Kamiriithu Community Education and Cultural Centre in Limuru, Kenya. This open-air theatre was comprised of a company of poor peasants, factory workers, and primary school teachers working collectively on collaboratively developed scripts. Playwright and political dissident, Ngugi Wa Thiong'o writes of that time as "the most exciting in my life and the true beginning of my education. I discovered the creative nature and power of collective work," $(1997: 133)^{\mathrm{v}}$. I am highlighting the work of this theatre group to illustrate that the populist theatre movement of the 1970's was intrinsic to education and social justice and that it appears to have occurred not only in western cultural movements but also in nonwestern revolutionary movements.

The Kamiriithu People's Theatre is central to the discourse in advancing African cultural studies as expressed in Wright's (1996) pivotal work, "Take Birmingham to the Curb, Here Comes African Cultural Studies: An Exercise in Revisionist Historiography." Western cultural studies seems to be oblivious to developments on or in and from the African continent and Wright's article pointed to this absence of Africa in genealogies of cultural studies by suggesting counter hegemony to the dominant western location (my italics) of cultural studies. Wright proposes an alternate account to locating the origins of cultural studies in such movements as the 1920's in Russia, the Harlem renaissance, the negritude movement of the 1930's, and the Kamiriithu community project in Kenya. Although not denying the importance of the Birmingham movement (Centre for 
Contemporary Cultural Studies - CCCS), Wright's basic identification of cultural studies is linked to the criterion of "performative acts" mostly operating beyond the academy. Instead these performative acts were community situated and inclusive of both males and females.

Tomaselli's (2000) essay, , "Recovering Praxis: Cultural Studies in Africa," is a response to Wright and in it Tomaselli pushes the counter hegemony argument further by suggesting that in the rush to publish, linked as it is to markets, money and power, praxis has been displaced and we are left with empty theorizing or navel gazing. In a later publication, Tomaselli (2001) laments the current trends in research methodologies whereby academics have distanced themselves from the field and fieldwork:

These are the scholarcrats of the international academocracy who often pour scorn on field workers who write about their research experiences in terms of arrival tropes, environmental hardships, and basic survival in remote and often dangerous places. (p. 283).

\section{Historical context}

As an inquiry, cultural studies was originally concerned with the study of power relations and democratization (my italics). In the 1970s and 1980s cultural studies was preoccupied with the debate between the structuralist and culturalists whereby the structuralists deconstructed existing power relations, which gave little voice to human agency and the culturalists emphasized experience, class as consciousness and historically grounded descriptions of social conditions. ${ }^{\mathrm{vi}}$ The disappearance of the social in post 1990 cultural studies shifted attention away from material factors and encouraged a form of textually based analysis of the "popular", "difference" and subcultures of style. Tomaselli (2004) indicates that, "Where the culturalist tradition had potential as a method applicable in policy and human rights research, the post structuralist had made little impact in this area." (p. 258). Wright (1998) also notes that the institutionalization of cultural studies has diminished "the possibility of conceptualizing and utilizing cultural studies as a tool that accomplishes certain socio-political ends both within the academy and, more importantly, in communities and society at large" (p. 37).

The maturation of cultural studies as a commodity and its post-structural focus on the performativity of text as endgame in and of itself has left little room for those whose intent in cultural practice is one of informing peace education through experiential social justice praxis. However, there seems to be a growing number of nonwestern cultural practitioners and theorists who want to reposition cultural studies within the discourse of social justice and human rights. Tomaselli's (1999) idea of dynamic justice, the value ideas of freedom and life chances, demands that cultural studies returns to the basically moral project of inquiry into social justice and that this inquiry have global reach. The idea of dynamic justice can frame a research area with a plurality of disciplines carrying on inquiry into a single topic. Dynamic justice then refers to cooperative research involving many disciplines and as Tomaselli suggests, "ought to remain the guiding principal of cultural studies," (p. 263). He calls for a return to the social versus the textually based analysis of popular culture, informing cultural studies as performative inquiries utilizing participatory and community-based experiences in the field. 
Life skills and health education projects drawing on cultural studies and action research, participatory communication, Augusto Boal's (1974), performative strategies and Paulo Freire's (1994) critical pedagogy, has become the norm across a range of activities all over Africa. Rather than necessarily assuming the dichotomy between the head (academy) and the hand (the terrain of popular experience), many of these applications linked educational institutions and grass roots initiatives with communities and of struggle, across the continent.

This same ideology brought Mpambo delegates-educators, activists, artists and investors in academe, civil society and the private and public sectors - to Jinja, Uganda, in order to develop a North and South dialogue that explored cross-cultural, cross paradigmatic and inter-civilization frameworks. This inclusive framework allowed participants to move towards a hegemony that countered the western canon and gave voice to those voices that have been silenced or forgotten. Hall (2000) articulates the movement, within both the academy and the local community that draws attention to the situation that subordinates:

People's knowledges, histories and experiences have been left out of academic texts, discourse and classroom pedagogies, or have been erased from them. These hitherto silent and silenced voices are no longer willing to accept the status quo and are urging that the problems associated with systemization and commodification of knowledge be addressed (p. 3).

So, here we were, people gathered together who dared to dream of a different world of peace, social progress, justice, self-determination and solidarity, using principles of participatory (practice based) education pedagogy. "In participatory research all members of the community support one another in an ongoing manner to actively inform the purpose, context, methodology and emerging data of the work," (Hall 2000). ${ }^{\text {vii }}$ This methodology facilitates a community of both learners and educators.

\section{Lake Victoria, June 8, 2004}

At night the fish boat lights glimmer across the surface of Lake Victoria, a pearl necklace bobbing in the midnight sky, revealing the shadows of fishermen casting their silver nets out into the cool waters of the deep lake - so still at night for fishing. Dawn comes around 5:00 am, an hour or so after my neighbour James throws his late night flashlight across my covered, curtained windows. James, a boisterous African American from Chicago and Viet Nam veteran, has given me laundry tips for my meager wardrobe. The trick is to throw your clothes in the shower and stomp on them while you're washing...then just rinse and hang to dry. He's also supplied me with a key ring flashlight so I can get into my room at night.

I have discovered the benefits of ordering coffee, for next to nothing, at my room in the morning. I sit on my balcony and watch the light come up across the lake as the fish boats come ashore. This great Lake Victoria, which just a decade ago conveyed the bloated remnants of Rwanda's carnage, thousands of bodies swept towards the dam at the source of the Nile. Perhaps they were returning home for the final time. As I sit here on the balcony sipping coffee with my view of privilege, it seems impossible to imagine the 
etymology of the Rwandan ethnic conflict and especially how the rest of the world (including myself) abandoned the Rwandan people.

In Appiah's (1992) chapter, “African Identities”, from In My Father's House, he provides a cautionary note in looking at Africans from a position that has been largely theorized as "racial" or "tribal". As a theorist, he claims it is impossible for him to live through the "falsehoods of race and tribe and nation", whose understanding of history makes him skeptical that "nationalism and race solidarity can do the good that they can do without the attendant evils of racism; without the warring of nations," (p. 175). Appiah seems to foretell the horrors, which were visited upon Rwanda because of this "tribal" divide, as the "constantly shifting redefinition of tribal identities to meet the economic and political exigencies of the modern world," (p. 177). Many people at the conference were returning to Africa for the first time in their family's history and it was an extremely emotional and moving event to witness.

Much of the conference was related to witnessing and reclaiming heritage. This meant moving beyond the colonial dictated nation states and bringing forward the indigenous knowledge of cultures, which were repressed and in some cases eradicated through colonization. Wangoola's (2000) philosophy to rekindle the African spirit is embodied in Mpambo as a "living symbol of true African spirit, identity, and consciousness, and of the commitment to diversity in nature and in social life" (p. 274).

Mpambo is a popular movement - a forum for individuals, groups, institutions, and other parties interested in promoting African thought and development. As an education-cum development ideology, it utilizes people's heritage and creative energies to promote development. Central to the development objectives is Mpambo Multiversity, a community knowledge bank from which the community and others can draw on the basis of need. "A multiversity differs from a university insofar as it recognizes that the existence of alternative knowledges as important to human knowledge as a whole," (Wangoola 2000:273). It believes that a new synthesis between indigenous knowledges and modern scientific knowledge is necessary to provide sustainable solutions within African communities.

Mpambo's conference theme was about dreams and renewal. Mpambo means "seed"-specifically pumpkin seed - and this global conference at the source of the Nile River cultivated seeds in our hearts and minds as we began to develop alternatives for global justice through education. By bridging both indigenous knowledge and contemporary global methods, we combined ritual and discourse to create a body of knowledge that premises all knowledges as having value and therefore all voices have equal value. As an example of how we combined the past with the present, we preformed an opening ceremony ritual. Paulo had emailed us prior to leaving for the conference and asked us to bring a small amount of water and earth from our homes. After the king, His majesty, Isebantu Kyabazinga of the Busoga Kingdom, gave his opening remarks we individually placed our earth and water in a large clay urn and planted a tree. The tree became the symbol of our collective knowledges and identities.

\section{Hotel Triangle, June 9, 2004}

Olasumbo has left a note tucked into my door suggesting I come down to her room and get some clothes. Down in her room, Olasumbo explained that since I was away from my 
Nigerian partner, it was the Nigerian custom for her to take on the role of the husband. Well, Olasumbo, Virgie, and Anthonia gave me the most beautiful clothes - they are works of art in and of themselves: A fitted, pink hand-painted outfit, a wrap around tie and dyed, blue skirt and top, which we agreed I should wear for my presentation and a pink cotton nightie for bedtime. I'm completely set now. It is strange how much of our identity is tied up in what we wear... what we present to the world. The girls (Oh, I know they are not girls, they are women all in their fifties and what powerful forceful women they are!) and I have formed a pact of sisterhood.

Appiah observes in "Who's Culture Is It Anyway?" (2006) to art through identity is powerful. He states that "Another connection, the one neglected in talk of cultural patrimony, is the connection not through identity but despite difference. We can respond to art that is not ours; indeed we can fully respond to our art only if we move beyond thinking of it as ours and start to respond to it as art. But equally important is the human connection. They are among the realest connections we have" (p. 135).

\section{Collective Identities}

The African could only say I am, because we are: and since we are, therefore I am. J.S. Mbiti, 1969 (p. 108)

The notion of collective identities is found in many African and indigenous cultures that see the other as embodied in the self. Feminist theory calls this idea "the full self." ix A core objective of Mpambo is to halt the erosion of African collective identities. Within these collective identities storytelling is a major contributing component. There is a familiar African tale told by Appiah (2006), in his philosophical work In My Fathers House: a peasant is stopped by a traveler in a large car and asked the way to the capital. "Well," she relies, after pondering the matter for a while, "if I were you, I wouldn't start from here." So, I am going to step away from cultural studies theories for a moment and look specifically at social movement and human rights discourse. We can then begin to see that collective identities play a crucial role in the relationship between culture and social movements.

Western liberal epistemology, with its predominant focus on the individual, does not prescribe to a notion of collective identities. As Ignatieff (1984), a liberal human rights scholar suggests: "There is no identity we can recognize in our universal. There is no such thing as love of the human race," (p. 52). ${ }^{\mathrm{x}}$ Rajagopal (2003) a nonwestern human rights scholar, suggests that social movements arise as a challenge to liberalism, Marxism, and by extension to extant theories of international law, including human rights law by enacting a unique form of politics, which he labels cultural politics. According to Rajagopal, "What distinguishes social movements from human rights theory is that they result from the actual struggles of people, and not from an abstract a priori conception." (p. 253). In short, Rajagopal suggests that social movements seek to redefine the very definition of democracy by reconstituting the basis of civil society through counter hegemonic action.

Mario Diani (1992) identifies the following general elements in a social movement: 
1. It involves a network of informal interactions between pluralities of actors.

2. It is engaged in political or cultural conflicts.

3. It organizes on the basis of shared beliefs and collective identities.

The final elements of shared beliefs and collective identities again raise issues of how collective identities are formed. Some suggest that consensus mobilization is an ongoing part of a movement formation while others acknowledge that irreconcilable differences lead to a "process or realignment and negotiation between actors," (Rajagopal, 2003:239). Rajagopal believes that both these processes occur in many social movements and often simultaneously. "As gaps between different actors widen and consensus eludes them, realignment of identities begins to occur. This process is wholly different from the "right to identity" approach adopted by international law, which looks at identity as merely an individual choice," (p. 240).

\section{Outreach: Late afternoon, June 10, 2004}

Part of planting Mpambo seeds was conducting outreach work within the community schools and I was asked to give a lecture on music and social change to a group of young women at a teacher training college. As it turned out, it was only our small little Canadian contingent that went on the outreach mission, as transportation became a logistic nightmare, and our delegation was required to walk several kilometers in the blazing African heat. In rural Uganda, people walk. The experience of walking in Uganda alone is overwhelming because the soil, a deep iron oxide red, feels ancient. One gets a sense that the earth knows the bare feet of its ancestors - forgiving, regenerative and constant. I wondered how many generations of people passed across this same road, this same worn, red, sandy earth. The notion of kinship with the earth, animals and plants is deeply ingrained among the people. This notion is corroborated by (Wangoola 2000) having flashbacks in his childhood saying, "I remember as a little boy growing up on the plains of Busoga, begin troubled for days when I accidentally killed an ant." (p. 26).

This earth emanates a history of war, famine and dissent. The African migrates about the continent and thereby creates multicultural and transformative communities. These are exiles, expatriates of nation states with languages that evolved to reflect the different ethnicities and vernaculars. Yet, English - of the British variety - is still the language of learning. The school we visited was fashioned on the British tradition of Head Master and male teachers. To have a woman lecturer/instructor was a bit of a novelty. We arrived an hour late. The girls, by then, were involved in kitchen duties so, we faced a pack of rambunctious and hungry teenage boys. Teenage boys will be boys no matter where they are. Hormones are hormones - a global fact!

I had prepared a program based on Canadian folk music to illustrate some of the social justice issues in Canada - the environment, the land rights of First Nations peoples. But this college was a rural school, isolated from the world - there was no sense of globalization here. These students were not only unfamiliar with Canada - they had never even heard of Canada! So Canada was a foreign land and my Canadian accent was unintelligible. My first song "Clear Cut Trees"xi was about the massive clear cutting practices of global forestry companies. My class of teenage boys had no concept of clearcutting nor chain saws. Needless to say, the chain saw chorus was beyond comprehension 
- perhaps they thought this noise of the chain saws was a version of Canadian throat singing! Although they were trying to be polite and clapped after the song, I could tell I wasn't reaching any one. Some outreach! It is interesting to note that the construct of outreach can mean going beyond one's reach. I was demonstrating the definition or as they say in comedy - I was dying out there.

The boys needed a song with a beat - an ostinato - an up-tempo tune to capture their interest - to get them engaged. I began to clap a rhythm of Mmobomme, ${ }^{x i}$ an adaptation of an Ashanti prayer song, a fusion of African and Canadian music and lyrics. This was all that was needed. Together we clapped, danced and sang. Through this song, we finally began to connect - to share. I also began to grasp the meaning of "outreach" communication can only commence when first we "reach out" to establish a commonality. Music appears to establish a commonality as it functions beyond the specifics of a lexicon of ethnicity - even if one cannot understand the language, music creates meaning from rhythms. Music begins in the body; it begins with the heartbeat. Perhaps music, through its rhythm, is the universal heartbeat of mankind. After all, it was the beating drums that the Masters first silenced during slavery. ${ }^{\text {xiii }}$

Ogunshaye's (1972) an African scholar and artist suggests that, "In the world of culture we are all builders, all borrowers and lenders." (p. vii). Ogunshaye's idea supports two basic contentions: first, identity may be revealed by what we produce artistically, and second, we can preserve a portion of our identity through an interchange of artistic production and at the same time promote unity and understanding among peoples (Parrot, 1972). ${ }^{\text {xiv }}$

In looking at the construct of identity, it is interesting to note the entomology of the word. Identity originates in "sameness", a concept of identity as being "side by side." ${ }^{x v}$ The other concept of identity is one of repetition-over and over again. I suggest that it is through these interrelated properties of sameness and repetition that music operates by creating unification that animates our collective identities. ${ }^{\text {xvi }}$

\section{Music and Social Change}

In looking then, at the larger theme of music within social movements we find numerous historical incidents of music operating as a strong component of social change. For example, when the Czech rock band Plastic People of the Universe was first outlawed and arrested because the authorities said their Zappa-influenced music was "morbid" and had a "negative social impact," Vaclav Havel (1985) organized a defense committee; that, in turn, evolved into the Charter 77 organization, which set the stage for Czechoslovakia's broader democracy movement. As Havel wrote, three years before the Communist dictatorship fell, 'Hope is not a prognostication. It is an orientation of the spirit, an orientation of the heart.' xvii

The faith based music of the United States Civil Rights Movement during the 1950 s and 1960s is further evidence that music has the capacity to create solidarity against state sanctioned brutality and repeated human rights abuses. However, for all the documentation of the songs and voices such as those of Bernice Regan and Fannie Lou Hamer, there is little theoretical discourse of what it is about music that makes it such a formidable defense. Popular' culture provides some insight into music and social change especially as represented in several recent films. One, the remarkable Amandela! (2004) - 
- the story of music's definitive influence during the apartheid period in South Africa, and two, the Brazilian film, Favela Rising (2005) about the formation of Afro-Reggae groups to provide alternatives to street crime in the inner city slums (favelas) of Rio. These populist projects combine both narrative as documentary and music to illustrate how music can and does influence social change.

Music, as an oral tradition, has the ability to perpetuate the flow of culture between generations of peoples in a fluid and transformative manner. Music not only provides a historical continuity, but also, in performance becomes a representation of our collective identities. Given these attributes, music, and by extension culture, can bridge the communication gaps between cultures and ideas. And so, if we first acknowledge that communication involves a sense of vulnerability and hesitation, one can use music as a means to open the dialogue. The educator and learner, in turn, move from discourse to intercourse - from restriction to restitution - from governance to conference - from ignorance to acceptance.

\section{Source of the Nile: June 11, 2004}

It is late in the afternoon and I am sitting on a wooden slat at the prow of the twelve-foot long aging fish boat, we have hired to take us to the Nile. We round the curve of Lake Victoria and navigate through swirling eddies at the source of the river. The Nile is vast, wide and rapid as we are pulled by its current into the sunset. My pristine reverie is broken when I am told that the tangled wire mesh we navigated at the source was placed there to contain the dead from floating down the river! Always, there are reminders of war.

Yet, in this same current we also embrace the seeds of hope and renewal. Mpambo began by forming a transnational network/ community of like-minded peace educators who believe identity is a collective consciousness and that a better world is possible. To celebrate and reaffirm our collective identities we gathered in the cradle of civilization - at the source of the Nile - where we, in theory and practice, represented, "One People" with Multiple Dreams.

\section{Conclusion}

"Education is at the heart of any strategy for peace building." UNESCO Declaration of a Culture of Peace, 2000

My baggage finally arrived on the last day of the conference, completely intact. When I opened my case, I marveled at all that I had packed that I didn't really need. I decided to use this as a metaphor for western cultural discourse - we need to let go of some of our western baggage and open our minds and hearts to other ways of knowing. Sometime it is easier to do this when we leave some of this baggage behind as it gives us more room for new encounters.

Too much of our cultural discourse is clothed in western ideas, which have disconnected people from their culture and disconnected cultures from each other. Western based poststructuralist and postmodernist critiques of essentialist identity politics now consider identity passé, if not dangerously limited and limiting, (Wright 2002 , p. 811). Just as western cultural theorists are abandoning identity politics, the 
dominant western hegemonies are becoming more polarized towards "nationals/others" in order to protect their precious nation states. If cultural studies work wants to remain relevant as social justice praxis we must continue to interrogate notions of identity as complex, "multiple, overlapping, continuous and performative," (Wright 2002, p. 809) which are continually being constructed and deconstructed in everyday life:

The complexity of identity means that rather than being singular or merely replacing one form of identity for another (e.g. ceasing to be Krio and becoming 'black') identity is a series of complimentary and contradictory identifications operating simultaneously, with some coming to the fore or receding depending on context" (Wright 2002: 811).

Theories of popular culture, concerned with identity politics and the construct of recognition are problematic, given so little representation of the very people the theorists wish to recognize. However, if we wish to locate human rights agency within cultural studies discourse then identity must be a crucial component of any culturally based theory. Cultural studies still aims to interrogate relationships of power within human endeavors and identity is embedded in these power relationships as both constructed and evolving. I question Spivak's (2006) definition of cultural studies as "founded by the colonized in order to question and correct their masters" (p. 359). I would suggest that cultural studies are still located in the world of the colonizer as the academy continues to promote western based postcolonial and postmodern discourse as represented in their curriculums. Indeed, postcolonial and poststructural discourse as frameworks provides limitations because contemporary theory has the task of "being too powerful, of having to prove too much." (Appiah, 1992, p. 65)

By looking at cultural theory from nonwestern based social justice discourse as articulated by Tomaselli's construct of dynamic justice, Wright's performative community based identification of cultural acts, and Rajagopal's idea of cultural politics, we can begin to see that collective identities play a crucial role in the relationship between cultural studies and social change. Rajagopal's idea of cultural politics as integral to social movements reaffirms Tomaselli's and Wright's call to relocate social justice praxis within cultural studies. These ideals challenge western epistemologies by articulating a counter hegemony that occurs within community based social movements organized on the basis of shared beliefs and collective identities.

If we can agree that our collective identity is a fluid and evolving phenomena, then we must look hard at our global acts and global responsibilities. It is not enough to lament the colonization of Africa - we must also acknowledge the ongoing human rights abuses in Africa that are largely ignored and, at the same time, perpetrated by the Western world. It is not enough to deconstruct the heart of Joseph Conrad - one ought to acknowledge a collective responsibility of past and present interventions. This involves actual representation of people in their own development rather than lip service and aid tied to western economic interests.

As Barber's (1997) work in Readings in African Popular Culture articulates, "In many discussions on development, the cultural aspect is left out or else admitted through the backdoor. And yet, if people are the center of development, then the quality of their life should be the most important indicator of development," ( $p$ 131). Going to the core of 
the problem, Wolfgang Sachs (1992) defines development as "a concept full of emptiness" and points out that "development thus has no content but it does possess a function: it allows any intervention to be sanctioned in the name of a higher evolutionary goal. Watch out!" (p.6)

So who is watching out? As educators and cultural workers we have the responsibility to question the exclusion of epistemologies that rest outside the dominant western narrative. "The university itself must not be overlooked as a site of praxis, a site where issues of difference, representation and social justice, and even what constitutes legitimate academic work are being contested," (Wright, 2002:p. 808) In fact, as educators we have the opportunity to construct social change within the academy. Surely, it is our obligation that:

Everyone has the right to education. Education shall be directed to the full development of the human personality and to the strengthening of respect for human rights and fundamental freedoms. It shall promote understanding, tolerance and friendship among all nations, racial and religious groups, and shall further the activities of the United Nations for the maintenance of peace (Universal Declaration of Human Rights, Article 26, 10 December, 1948). 


\section{References}

Appiah, K. A. (1992) In My Father's House: Africa in the Philosophy of Culture. Oxford: Oxford University Press.

Appiah, K.A.(2006) Cosmopolitanism: Ethics in a World of Strangers. New York: W.W. Norton and Company.

Barber, Karin (1997) Readings in African Popular Culture. Bloomington: Indiana University Press.

Boal, A. (1974) Theatre of the oppressed. Trans. Charles McBride and Maria-Odilia Leal McBride. London: Pluto.

Dei, S. G. J. (2002) African development: The relevance and implications of indigenousness. In G.J.S. Dei, B.L. Hall, \& D.G. Rosenberg (Ed), Indigenous knowledges in global contexts: Multiple readings of our world (pp. vii-x). Toronto: University of Toronto Press.

Diani, M. (1992) The concept of social movement. Sociological Review, 40, 1-25.

Freire, P. (1994) Pedagogy of hope. New York: The Continuum Publishing Company.

Grossberg, L. (2004) Dancing in spite of myself: Essays on popular culture. Durban, NC: Duke University Press.

Ignatieff, M. (1984) The Needs of Strangers. Toronto: Elizabeth Sifton Books.

Loeb, P. R. (2004) (Ed.) The Impossible Will Take a Little While - a Citizens Guide to Hope in a Time of Fear. New York: Basic Books.

Mbiti, J. S. (1969) African religious and philosophy. New York: Frederick A. Preager.

Nyamnjoh, F. B. (1999) African Cultural Studies, Cultural Studies in Africa: How to make a Useful Difference. Critical Arts: A South-North Journal of Cultural and Media Studies, 13 (1) p. 15-25.

Parrott, F. J. (1972) Introduction to African Arts. New York: Arco Publishing Company Inc., 1972. Quote by Ayo Ogunshaye appears in Foreword vii.

Rajagopal, B. (2003) "Recoding resistance: Social Movements and the Challenge to International Law," International law from Below: Development, Social Movements and Third World Resistance. Cambridge: Cambridge University Press.

Rajagopal, B. (2003) "Writing Third World Resistance into International Law" International law from Below: Development, Social Movements and Third World Resistance. Cambridge: Cambridge University Press.

Southern, E. (1983) The Music of Black Americans $2^{\text {nd }}$ Edt. New York: W.W. Horton and Company.

Spivak, G. C. (2006) Culture alive - Problematizing global knowledge. Theory, culture and Society 23, (2-3) 359-360.

Tomaselli, K.G. (1999) Encounters in the Kalahari (theme issue). Visual Anthropology, $12(2-3)$.

Tomaselli, K.G. (2000) Recovering praxis: cultural studies in Africa. European Journal of Cultural Studies. 1 (3), 387-402.

Tomaselli, K.G. (2001) Blue is hot, red is cold: Doing reverse cultural studies in Africa. Critical Studies, Critical Methodologies, 1, (3), 283-318.

Tomaselli, K.G. (2004) Cultural studies is the crisis: Culturalism and dynamic justice. Critical Studies, Critical Methodologies 4, (2), 257-268. 
UNESCO (2000) Education for a Culture of Peace: Peace, Human Rights and Democracy Education. Declaration and Programme of action on a Culture of Peace Project \#UN/GA/A/Res/53/243. Retrieved Sept. 29, 2006 from http://www.unesco.org/cpp/uk/declarations/2000.htm.

UNESCO, (1948). Universal Declaration of Human Rights. Article 26, 10 December, 1948. Retrieved Sept. 29, 2006 from, http://www.unesco.org/education/ecp/publicat/brochure/english/intro.html,

Vaclav, H. (1985) The power of the powerless: Citizens against the state in CentralEastern Europe. Ed. John Keane. Armonk, New York: Sharpe Inc.

Wangoola, P. (2002) Mpambo, the African multiversity: A philosophy to rekindle the African spirit. In G.J.S. Dei, B.L. Hall, \& D.G. Rosenberg (Ed), Indigenous knowledges in global contexts: Multiple readings of our world. Toronto, ON: University of Toronto Press.

Wright, H. (2004) A Prescience of African Cultural Studies. New York: Peter Lang.

Wright, H.K. (1996) Take Birmingham to the curb, here comes African cultural studies: An exercise in revisionist historiography. University of Toronto Quarterly, 65, (2), 355- 365 .

Wright, H.K. (1998) Dare we de-centre Birmingham?: Troubling the 'origin' and trajectories of cultural studies. European Journal of Critical Studies, 1 (33).

Wright, H.K. (2002) "Notes on the (Im)Possibility of Articulating Continental African Identity." Critical Arts, 16 (2), 1-18.

Wright, K.K. (2003) Cultural studies as praxis: (Making) an autobiographical case. Cultural Studies 7, (6), 805-822.

${ }^{\text {i }}$ Fluxus -a way of fusing certain radical social attitudes with ever--evolving aesthetic practices. Initially received as little more than an international network of pranksters, the admittedly playful artists of Fluxus were, and remain, a network of radical visionaries who have sought to change political and social, as well as aesthetic, perception.

ii Example of these videos can be found in archival collections at the National Gallery, Ottawa and the Western Front Society, Vancouver. BC. See: Hunt L. A. Pearl (1980). Entertainment Tonight; Metcalfe, Eric (1980) Steel and Flesh (1980), my lyrics and music for "Hot For You Baby"; and Dean, Tom (1982) Fear of Blue.

iii International Centre for Contemporary Asian Art, Vancouver, B.C.,2004. Located in Vancouver's downtown east side which is infamous for being the poorest postal code in Canada. Recent media reports indicated there are over 1,000 homeless in this area.

${ }^{\text {iv }}$ Quote from introduction to: Wright, H. (2004) A Prescience of African Cultural Studies New York: Peter Lang.

v From: Barber, Karin (1997) Readings in African Popular Culture. Bloomington: Indiana University Press. Ngugi Wa Thiong'o "Women in Cultural Work: The fate of the Kaminiithu People's Theatre in Kenya, “" (p 131-138).

${ }^{v i}$ From Tomaselli, K.G. (2004) "Cultural Studies is the Crisis: Culturalism and Dynamic Justice." Critical Studies, Critical Methodologies 4 (2) p. 257-268.

viic“From the "Introduction" in Indigenous Knowledges in Global Contexts, (2000) Edited by Dei, Hall \& Rosenberg. Toronto, Ont.: University of Toronto Press.

viii From Appiah, K.A. Cosmopolitanism: Ethics in a World of Strangers. New York: W.W. Norton and Company. 
${ }^{\text {ix }}$ I first became aware of this concept while visiting Highlander Research and Education Center, Tennessee, in 2000. This construct is articulated in The Highlander Way (Hunt, 2002: 39).

${ }^{\mathrm{x}}$ Ignatieff, Michael (1984). The Needs of Strangers. Toronto: Elizabeth Sifton Books. Pp. 52-53.

${ }^{x i}$ Kenyon, Lindsay (1990). Clear Cut Trees, (words and music). Performed with permission of composer/author.

xii Hunt, Pearl 2004 Mmobomme, words and music. First performed at Simon Fraser University, Vancouver. April 2004.

xiii From Southern, Eileen, The Music of Black Americans 2nd Edt. New York: W.W. Horton and Company, 1983.

${ }^{\text {xiv }}$ Parrott, Fred J. Introduction to African Arts. New York: Arco Publishing Company Inc., 1972. Quote by Ayo Ogunshaye appears in Foreword vii.

${ }^{x v}$ Oxford English Dictionary $2^{\text {nd }}$ Edition. (1989). Clarendon Press: Oxford. Vol. VII pg $620-21$.

xvi Identity is a combination of idem, to express notion of sameness, plus Identidem, over and over again.

xvii From: Introduction "Orientation of the Heart". (2004). The Impossible Will Take a Little While - a Citizens Guide to Hope in a Time of Fear. Ed. Paul Rogat Loeb, New York: Basic Books, p.5

xviii From Wright, H.(2004) A Prescience of African Cultural Studies New York: Peter Lang, p.137-8. 